\title{
Employing Geochemical Analysis to Reveal Pedogenic Processes in Wisconsin Bisequal Soils Having Spodic and Alfic Sequa
}

\author{
Michael Aide*, Christine Aide \\ Southeast Missouri State University, Cape Girardeau, Missouri, USA \\ Email: *mtaide@semo.edu
}

How to cite this paper: Aide, M., \& Aide, C. (2020). Employing Geochemical Analysis to Reveal Pedogenic Processes in Wisconsin Bisequal Soils Having Spodic and Alfic Sequa. Journal of Geoscience and Environment Protection, 8, 1-25. https://doi.org/10.4236/gep.2020.811001

Received: October 2, 2020

Accepted: November 3, 2020

Published: November 6, 2020

Copyright $\odot 2020$ by author(s) and Scientific Research Publishing Inc. This work is licensed under the Creative Commons Attribution International License (CC BY 4.0).

http://creativecommons.org/licenses/by/4.0/

\section{Open Access}

\begin{abstract}
Bisequal soils in northern Wisconsin were described and characterized with the intent to determine if a near total elemental analysis protocol may estimate the effect of selected soil pedogenic pathways on soil morphology. The protocol reveals that gross elemental soil profile distributions do provide evidence that certain pedogenic processes are operating within a group of soils. Concentration differences between instrumental neutron activation analysis and an aqua regia digestion protocol infer that alkali metals, alkaline earth metals, transition metals and the rare earth elements are only incompletely weathered from primary minerals. Transition metals, alkali metals, alkaline earths, metalloids, and the rare earth elements all show inter-horizon mobility. Lessivage and the mobility of elements presumably adsorbed on soluble or suspended organic materials are the dominant soil processes influencing the soil profile redistribution of elements and the majority of these elements are shown to correlate with the soil profile distribution of Fe. Base cycling by the forest vegetation was shown to support A horizon enrichment of $\mathrm{Ca}, \mathrm{Sr}, \mathrm{Ba}$, $\mathrm{P}, \mathrm{S}, \mathrm{Mn}, \mathrm{Zn}, \mathrm{Sn}$ and $\mathrm{Pb}$. For clinical practice, elemental analysis may reveal important soil profile elemental differences when applied to variation of one soil forming factors, such as a chronosequence or toposequence within a landscape or soil association. Advantages and limitations of the protocol in identifying pedogenic pathways are discussed.
\end{abstract}

\section{Keywords}

Geochemical Analysis, Alfisols, Spodosols, Bisequal Soils, Soil Genesis

\section{Introduction}

A bisequal soil is a soil that possesses two sequences of soil horizons that are 
generally associated with different soil orders. In the present case, we discuss A-E-Bs sequum's associated with a Spodisol over-lying a B/E sequum's with the $\mathrm{B}$ component having Bt characteristics, which are commonly associated with an Alfisols and Ultisols. Hole (1975) investigated bisequal soils having a spodic sequum overlying an alfic sequum in northern Wisconsin and contended that contrasting climate-vegetation variations supported creating the alfic profile followed by spodic horizon development, which resulted in the bisequal soil profile. Bockheim (2003) performed a similar study in northern Wisconsin and concluded that the spodic and alfic sequa evolved contemporaneously with the dominant influence being the presence of a lithologic discontinuity. Bockheim concluded that the greater clay content of the alfic sequum was formed by neoformation of clays with some clay migration. The soil processes responsible for these bisequal soils are currently operating and are assisted by rapid spring snowmelt supporting base cation leaching. In the Sylvanic Wilderness-Recreation area of western upper peninsula Michigan having bisequal soils, Bockheim and Jordan (2004) documented evidence of podzolization, lessivage, and in some sites fragipan formation. The upper portion of the soils shows clay illuviation, leaching of exchangeable bases $(\mathrm{Ca}, \mathrm{Mg}, \mathrm{K})$, and in some cases silt migration. Textural discontinuities restrict water percolation leading to clay enrichment.

Schaetzl and Isard (1996) showed that northern Wisconsin spodosols dominate the landscape where 1) frost and thaw activity is minimal, 2) soil temperatures rarely exceed $16^{\circ} \mathrm{C}-17^{\circ} \mathrm{C}$, and 3) snowpacks are comparatively thick and support appreciable spring water infiltration/percolation. Bockheim (2003) observed glossic horizons in the western Great Lakes Region and proposed that glossic horizons form from the degradation of argillic horizons, wherein clay and $\mathrm{Fe}$ are redistributed to form $\mathrm{E} / \mathrm{B}$ and $\mathrm{B} / \mathrm{E}$ horizons. The majority of the glossic-bearing soils lie in a belt north of the transition from mesic to frigid soil temperature regimes, which is also the boundary between the location of major late Wisconsin end moraines and a non-forest to forest transition (Bockheim and Jordn, 2004; Bockheim and Hartemink, 2016).

Whittig and Jackson (1954) demonstrated a mixed clay mineralogy for spodosols in northern Wisconsin. The dominant clay minerals were randomly interstratified vermiculite-chlorite and vermiculite-montmorillonite in the fine-silt and clay fraction. The profile distribution showed illite and chlorite in the $\mathrm{C}$ horizons with vermiculite and especially montmorillonite increasingly evident in the leached-eluvial horizons. Madison and Lee (1965) observed that the sand fractions of selected Wisconsin Spodisols have an abundance of quartz, with appreciable quantities of orthoclase and heavy minerals. Buol and Hole (1959) documented characteristics of clay films on structural peds in gray-brown podzolic (Spodosols) soils. Clay film analysis supports clay (vermiculite and chlorite-vermiculite intergraded) and Fe enrichment greater than that of the bulk soil. Thin sections showed the clay films to be composed of thin clay lamellae. In a classic study, Richardson and Hole (1979) investigated mottling on a glossoboralf-Haplaquoll sequence on a glacial moraine in northwestern Wisconsin. 
Mottle development was greatest in somewhat poorly drained sites, whereas poorly drained sites exhibited gleization was predominant. In all soils, evidence indicated that Fe migrated from the eluvial to illuvial horizons or exited the soil profile. Base on selective extractions, Fe-oxyhydroxide crystallinity was the greatest in the well-drained sites.

\subsection{The Spodic Horizon as a Diagnostic Horizon}

The spodic horizon is an illuvial horizon that exhibits an accumulation of free $\mathrm{Al}$ and Fe-bearing sesquioxides and/or organic matter and is more than $2.5 \mathrm{~cm}$ thick (Buol et al., 2003). Spodosol formation is typically associated with mobilization and eluviation of aluminum and iron from the $\mathrm{O}, \mathrm{A}$ and $\mathrm{E}$ horizons and subsequent immobilization of these elements in the spodic horizon. Spodic horizon formation is very often associated with organic acids liberated from the forest floor, especially in coniferous forests. These Al-organic and Fe-organic complexes may leach from the $\mathrm{O}, \mathrm{A}$ and $\mathrm{E}$ horizons. Immobilization in the spodic horizons is supported by differences in 1) $\mathrm{pH}, 2$ ) soluble silicon, Al- and Fe-organic complex sorption, 3) precipitation of organic complexes by a greater presence of available $\mathrm{Al}$ and/or Fe (Browne, 1995). The neoformation of imogolite or allophane generally occurs when labile silicon is present. Bazilevskaya et al. (2018) noted that submicron mineral phases suspended in soil pore water provide a major pathway for organic carbon transport. The smallest size fractions (less than $0.45 \mu \mathrm{m}$ ) showed organic mass concentrations substantially greater than the $\mathrm{Fe}$ and $\mathrm{Al}$ mass concentrations, where chemical equilibrium modeling suggests that these metals are organically complexed. The authors suggest that the downward transport organic bearing colloids in percolating water (organic colloids, organic material adsorbed onto mineral phases, and organic-mineral phases) continues until transport is immobilized by $\mathrm{pH}$, water absorption, or increased metal to carbon ratios. Spodosol evolution remains an area of research (Aide and Pavich, 2002; Browne, 1995; Buol et al., 2003; Bazilevskaya et al., 2018).

\subsection{The Argillic Horizon as a Diagnostic Horizon}

The argillic horizon is "an illuvial horizon that contains 1.2 times as much clay as some horizon above or contains $3 \%$ (absolute) more clay content if the horizon above has less than $15 \%$ clay or contains $8 \%$ more clay if the horizon above has more than $40 \%$ clay" (Buol et al., 2003). It is likely that neoformation of clay within the argillic horizon occurs in most Alfisols and Ultisols. Typically, the argillic horizon exhibits clay bridges, clay films or clay linings in pores. Clay translocation (lessivage) is particularly prominent when the following conditions are satisfied: 1) previous loss of calcium carbonate as a cementing agent, 2) structure dispersion and eluviation-illuviation from the A and E horizons, 3) preferential transport of fine clay, 4) sufficient rainfall or rapid snow melt creates sufficient percolating water to advance leaching conditions. Soil conditions that arrest the continuation of clay from the argillic horizon include: 1) absorption of 
percolating water by structural peds, 2) presence of shrink-swell clays that slow water percolation, 3) clay lining growth in pores that reduce water passage, 4) clay flocculation by calcium, aluminum or other cations, 5) the reduction of water percolation may be correlated with clay neoformation within the argillic horizon (Buol et al., 2003).

\subsection{Lithologic Discontinuities}

A lithologic discontinuity is defined as a layer within the soil profile that is distinguished because of geologic process rather than a pedogenic process, which typically is associated with a transition from one parent material to another. Soil features suggesting that lithologic discontinuities exist include: 1) an abrupt textural contact, 2) contrasting size distribution in the sand separate, 3) particle size differences on a clay-free basis, 4) differences in trace minerals, and 5) presence, shape and orientation of material larger than $2 \mathrm{~mm}$. If the feature is related to the present landscape, then greater or more compelling evidence is required to suggest the difference is not attributed to a pedogenic process.

\subsection{Elemental Mobility in Soil Profiles}

Elemental mobility has been and continues to be an area of active research (Aide and Smith-Aide, 2003; Aide and Braden, 2009; Aide and Aide, 2012). Research has focused on 1) mechanisms responsible for element transfer among soil horizons and 2) which elements tend to have the least mobility and thus may be used to index other elements to estimate their mobility likelihood or intensity of inter-horizon transfer (Aide and Braden, 2009; Aide et al., 2011; Aide, 2018; Brown et al., 2003; White, 1995). Element mobility within the soil profile may be partitioned as the migration of chemical species because of 1) diffusion or convection of water soluble species as simple ions, hydroxy species or ion-pairs, 2) eluviation-illuviation of an adsorbed or occluded element onto phyllosilicates or onto oxyhydroxide coatings covering phyllosilicates, 3) leaching of organic species that form complexes with ionic species, and 4) biocycling (also termed base cation enrichment) wherein species are root absorbed and transported to areal plant portions where they are subsequently returned to the soil surface as residues or litter (Langmuir, 1997; Fujinuma et al., 2005). We also recognize that wind/water erosion and sediment deposition, atmospheric deposition and soil amendments may be important pathways. Inter-horizon elemental mobility may be arrested in the receiving soil horizons by conditions that promote 1) the accumulation of illuviated clay, 2) changes in $\mathrm{pH}, 3$ ) sufficient adsorbed metals on organic species to foster colloid formation and precipitation, 4) sorption into existing oxyhydroxides, phyllosilicates, accumulated calcium carbonates, and 5) similar chemical and physical phenomena.

The research objectives are to determine the effectiveness of a low-cost aqua regia digestion protocol to obtain soil profile elemental distribution patterns to qualitatively infer the intensity of key soil formation processes in soil morphology. We stress that only a qualitative inference is possible because a near total 
elemental analysis will not reveal the multiple element interactions with soil organic matter, oxyhydroxides, phyllosilicates, carbonates, or lattice associations. We also acknowledge that every element is mobile to some extent and that multiple pedogenic pathways are simultaneously operating with different element redistribution outcomes. Lastly, given multiple soil processes that support soil profile horizonation and haploidization, the evolutionary history of a soil is complex.

\section{Materials and Methods}

\subsection{Study Area}

The study area is in Florence County, Wisconsin (Lat: 45.8531, Lon: -88.6386) near Halsey Lake. The continental climate is cold with an average annual temperature of $3.9^{\circ} \mathrm{C}\left(39.1^{\circ} \mathrm{F}\right)$, with January temperatures averaging $-12.6^{\circ} \mathrm{C}$ $\left(9.2^{\circ} \mathrm{F}\right)$. Annual rainfall averages $0.77 \mathrm{~m}$ (30.4 inches) with July rainfall averaging $0.094 \mathrm{~m}$ (3.7 inches). Vegetation in the sampling area is northern hardwoods, with dominant trees including sugar maple (Acer saccharum), with abundances of American basswood (Tilia americana), yellow birch (Betula alleghaniensis), northern red oak (Quercus rubra), eastern hemlock (Tsuga canadensis), aspen (Populus tremuloides) and paper birch (Betula papyrifera). Landforms in Florence County are almost exclusively glacial. Ground moraines are numerous, along with end moraines, glacial lake plains, eskers, and bogs in depressional areas or slowly flowing small streams.

\subsection{Climate History of the Study Area}

The climate in northern Wisconsin from the existence of the Laurentide ice sheet to the present has been reasonably described (Bockheim and Hartemink, 2016; Clayton et al., 2001; Webb, 1974). Around 14,000 cal BP (cal BP is calibrated years before present) the Lake Superior-Chippewa, Green Bay and Lake Michigan ice lobes existed in northern Wisconsin. Retreat of the glaciers to the southwestern shore of Lake Superior and the Green Bay area occurred by 12,300 cal BP and by 11,800 cal BP the Laurentide glacier departed Wisconsin. During and after this interval vegetation consisted primary of spruce (Picea) and sedges. The Great Lakean advance reintroduced ice to northwestern Wisconsin and Green Bay. Permafrost was present throughout Wisconsin from 14,000 BP to $11,400 \mathrm{BP}$, creating a periglacial climate. From 8000 to $3000 \mathrm{cal} \mathrm{BP}$ northern Wisconsin exhibited a warmer and drier climate than the present. Near 9000 BP vegetation consisted primarily of Pine (Pinus) with birch (Betuta), elm (Ulmus) and aspen (Populus tremuloides) and by $6000 \mathrm{BP}$ the vegetation transformed to northern hardwoods (primarily white pine (Pinus strobus), maple (acer) and birch (Betuta). Since $3000 \mathrm{cal}$ BP the climate became cooler and wetter than the present and the vegetation transitioned to northern hardwoods with hemlock (Tsuga) as a key species.

The Padus series (coarse-loamy, mixed, superactive, frigid Alfic Haplorthods) 
has been described previously (Aide and Pavich, 2002) and consists of pedons having an A-E-Bs-E/B-B/E horizon sequence developed on glacial outwash. Spodosols are mineral soils that have a spodic horizon (Buol et al., 2003). The sampled pedons reside in the Chequamegon-Nicolet National Forest in north-central Wisconsin and are distant from highway traffic and residential areas. The Sporley series (Coarse-silty, mixed, active, frigid Alfic Haplorthids) consist of very deep, well-drained soils formed in silty glaciolacustrine deposits on dissected moraines and lake plains having an A-E-Bs1-E/B and/or B/E-C horizon sequence. The excavated Sporley-like pedon was in an area mapped as Sporley; however, the pedon lacked evidence of the presence of the Bs horizon, suggesting that the Bs horizon degraded. The Padus and the associated Sporley-like series (Glossudalfs) was selected because the pedons exhibit a spodic or spodic-like sequum, overlying an alfic sequum.

\subsection{Soil Profile Characterization}

The Padus pedons were previously characterized for morphology and routine chemical properties (Aide and Pavich, 2002). The Padus pedon \#1 is strongly acid, exhibits substantial soil organic matter in the A horizon that becomes less abundant with increasing soil depth, and has a low $\left(<12 \mathrm{cmol} \cdot \mathrm{kg}^{-1}\right)$ cation exchange capacity (CEC). The Padus \#2 pedon is moderately acid in the upper soil profile (spodic sequum) and is slightly acid in the alfic sequum (Table 1). Soil organic matter is more abundant in the A horizon and declines in abundance with increasing soil depth. Like the Padus \#1 pedon, the exchangeable calcium and CEC are greater in the A horizon and declines with increasing soil depth, paralleling the soil organic matter content. Both pedons are coarse-textured with a small clay content and each demonstrates a lithologic discontinuity, transitioning to gravelly outwash sand. X-ray diffraction of the clay separate established a mixed mineralogy with vermiculite and kaolinite as the dominant phyllosilicates, with secondary quantities of hydrous mica and trace quantities of smectite in the E horizon.

The Sporley-like pedon is moderately acid in the upper portion of the soil profile and becomes strongly and very strongly acid in the alfic sequum. The Sporley-like pedon has a silt loam texture, a low to medium (12 to $18 \mathrm{cmol} \cdot \mathrm{kg}^{-1}$ ) cation exchange capacity and has considerable exchangeable and non-exchangeable acidity (Table 1). The soil organic matter content is greatest in the A horizon and declines to very small abundances at greater depths.

\subsection{Methodology}

Soil $\mathrm{pH}$ using equal volumes of soil and water, ammonium acetate $(\mathrm{pH} 7)$ extraction of exchangeable cations, total acidity by titration to $\mathrm{pH} 8$, organic matter content by loss on ignition and mechanical analysis by dispersion, sieving and centrifuge separation were performed using protocols in Carter (1993).

An aqua-regia digestion (ARD) was employed to obtain a near total estimation of elemental abundance associated with all but the most recalcitrant soil 
Table 1. Physical and chemical characterization of the Padus and Sporley-like pedons.

\begin{tabular}{|c|c|c|c|c|c|c|c|c|}
\hline Horizon & $\begin{array}{l}\text { Depth } \\
(\mathrm{cm})\end{array}$ & $\mathrm{pH}$ & $\begin{array}{c}\mathrm{SOM} \\
(\%)\end{array}$ & $\begin{array}{c}\mathrm{ExCa} \\
(\mathrm{cmol} / \mathrm{kg})\end{array}$ & $\begin{array}{c}\text { Acidity } \\
(\mathrm{cmol} / \mathrm{kg})\end{array}$ & $\begin{array}{c}\text { CEC } \\
(\mathrm{cmol} / \mathrm{kg})\end{array}$ & $\begin{array}{l}\text { Clay } \\
(\%)\end{array}$ & Texture \\
\hline \multicolumn{9}{|l|}{ Padus \#1 } \\
\hline A & 5 & 5.5 & 10.1 & 8.4 & 0.2 & 10.2 & 5 & sl \\
\hline E & 18 & 5.3 & 3.9 & 4.3 & 0.3 & 5.6 & 3 & sl \\
\hline BS1 & 36 & 5.1 & 3.9 & 1.6 & 5.2 & 7.5 & 4 & sil \\
\hline $\mathrm{E} / \mathrm{B}$ & 46 & 5.2 & 1.8 & 0.1 & 2.9 & 3.7 & 4 & sil \\
\hline $2 \mathrm{BC}$ & 86 & 5.1 & 1.1 & 1.9 & 0.6 & 3.3 & 5 & $\mathrm{~g}$ ls \\
\hline $2 \mathrm{C}$ & 137 & 5.2 & 0.8 & 1.7 & 0.8 & 3.0 & 2 & $\mathrm{gs}$ \\
\hline \multicolumn{9}{|l|}{ Padus \#2 } \\
\hline A & 5 & 5.6 & 7.8 & 9.8 & 2.6 & 14.1 & 4 & sil \\
\hline $\mathrm{E}$ & 8 & 5.9 & 3.9 & 4.0 & 1.5 & 6.2 & 3 & sl \\
\hline Bs1 & 30 & 6.3 & 2.6 & 3.4 & 1.2 & 5.1 & 2 & sl \\
\hline $\mathrm{E} / \mathrm{B}$ & 43 & 6.4 & 1.4 & 3.3 & 1.4 & 5.4 & 4 & sl \\
\hline $2 \mathrm{BC}$ & 71 & 6.2 & 1.9 & 3.6 & 0.7 & 5.4 & 3 & g ls \\
\hline $2 \mathrm{C}$ & 127 & 6.0 & 1.0 & 1.6 & 0.3 & 2.8 & 3 & $\operatorname{vg} s$ \\
\hline \multicolumn{9}{|l|}{ Sporley-like } \\
\hline A & 9 & 6.0 & 5.3 & 7.9 & 4.0 & 13.6 & 4 & sl \\
\hline E1 & 12 & 5.9 & 2.6 & 3.3 & 5.5 & 9.9 & 5 & sl \\
\hline E2 & 24 & 5.6 & 1.1 & 1.7 & 6.0 & 8.5 & 5 & sil \\
\hline $\mathrm{E} / \mathrm{B}$ & 28 & 5.1 & 0.8 & 1.9 & 5.5 & 8.2 & 10 & sil \\
\hline $\mathrm{B} / \mathrm{E} 1$ & 38 & 4.9 & 0.7 & 4.5 & 7.0 & 13.2 & 11 & sil \\
\hline B/E2 & 50 & 5.0 & 0.5 & 5.1 & 6.0 & 13.0 & 13 & sil \\
\hline B/E3 & 60 & 4.9 & 0.5 & 3.1 & 5.0 & 9.4 & 8 & sil \\
\hline
\end{tabular}

SOM is soil organic matter, ExCa is exchangeable calcium, CEC is cation exchange capacity. Texture: $\mathrm{sl}$ is sandy loam, sil is sil loam, ls is loamy sand, $s$ is sand, $g$ ls is gravelly loamy sand, $\mathrm{vg} s$ is very gravelly sand The routine soil characterization for the Padus pedons was previously reported in greater detail in Aide and Pavich, 2002.

chemical environments. Aqua-regia does not appreciably degrade quartz, albite, orthoclase, anatase, barite, monazite, sphene, chromite, ilmenite, rutile and cassiterite, whereas aqua-regia partially degrades anorthite and phyllosilicates (Aide and Fasnacht, 2010). Homogenized samples ( $0.75 \mathrm{~g})$ were equilibrated with 0.01 liter of aqua-regia (3 volumes $\mathrm{HNO}_{3}$ to 1 volume $\mathrm{HCl}$ ) in a $35^{\circ} \mathrm{C}$ incubator for 24 hours. Duplicated samples were shaken, centrifuged, and filtered $(0.45 \mu \mathrm{m})$, with a known aliquot volume analyzed using inductively coupled plasma mass spectrometry (ICP-MS). Reference samples with known elemental concentrations were employed for quality control.

Instrumental neutron activation analysis (INAA) is employed to estimate the concentration of trace and major element concentrations in soils and sediments (Alfassi, 1994). A sample is subjected to a neutron flux and radioactive nuclides are produced. The radioactive nuclides decay and emit gamma ray's characteristic for each nuclide. Comparison of the decay intensity with standards permits 
quantitative concentration estimates, especially for elements with greater atomic numbers.

Oriented whole clay $(<2 \mu \mathrm{m})$ samples were prepared for X-ray diffraction. Magnesium-saturated and glycerol-solvated samples were air-dried on glass-slides, producing oriented mounts (Moore and Reynolds, 1989). X-ray diffractograms were obtained with a Scintag diffractometer using $\mathrm{CuKa}$ radiation (45 kv and $40 \mathrm{ma}$ ). Spectra were scanned from 2 to $30^{\circ} 2 \theta$ at $0.02 \mathrm{~s}^{-1}$. Peak areas were used to compare clay mineral differences among soil horizons. Peak areas were determined after background removal and were calculated from the product of peak height and half-height peak width. Peak positions of 1.77 to $1.8 \mathrm{~nm}$, 1.4 to $1.5 \mathrm{~nm}, 0.99$ to $1.01 \mathrm{~nm}$, and 0.71 to $0.72 \mathrm{~nm}$ were used to identify smectite, hydroxy-Al interlayered vermiculite, clay mica and kaolinite, respectively (Moore and Reynolds, 1989). It is recognized that peak areas are not useful in estimating individual clay mineral abundances; however, changes in the percent of peak area attributed to a given clay mineral within a soil profile may be useful to qualitatively show abundance differences throughout the soil profile.

\section{Results and Discussion}

\subsection{Alkali Metal Elements}

Alkali metal elements are six elements in Group 1 (Ia) of the periodic table. Comparing sodium $(\mathrm{Na})$, rubidium $(\mathrm{Rb})$, and cesium $(\mathrm{Cs})$ concentrations between aqua-regia digestion and instrumental neutron activation analysis shows at least an order of magnitude difference in the individual element concentrations, with INAA considered a total analysis (Table 2). Lithium (data not

Table 2. Concentration (mg/kg) comparison of sodium ( $\mathrm{Na}$ ), Rubidium $(\mathrm{Rb})$ and Cesium (Cs) from aqua-regia digestion (ARD) and Instrumental Neutron Activation Analysis (INAA).

\begin{tabular}{ccccccc}
\hline & Na-ARD & Na-INAA & Rb-ARD & Rb-INAA & Cs-ARD & Cs-INAA \\
\hline Padus \#1 & & & & & & \\
A & 150 & 5800 & 8.2 & 64 & 0.73 & 5 \\
E & 500 & 6370 & 7.6 & 34 & 0.75 & 4 \\
Bs1 & 250 & 6720 & 5.8 & 85 & 0.73 & 4 \\
E/B & 290 & 7570 & 7.6 & 109 & 0.72 & 6 \\
2BC & 550 & 6710 & 11.9 & 36 & 1.16 & 7 \\
2C & 970 & 7740 & 23.2 & 31 & 3.35 & $<3$ \\
Padus \#2 & & & & & & \\
A & 160 & 6330 & 9.5 & 96 & 0.85 & 3 \\
E & 470 & 6800 & 11.1 & 58 & 0.96 & 3 \\
Bs1 & 360 & 6810 & 9.4 & 94 & 0.85 & 5 \\
E/B & 330 & 6990 & 9.3 & 93 & 0.82 & 5 \\
2BC & 590 & 7210 & 13.1 & 59 & 1.43 & $<3$ \\
2C & 780 & 7550 & 31.7 & 96 & 3.91 & 3 \\
\hline
\end{tabular}


shown), $\mathrm{Na}, \mathrm{Rb}$, and $\mathrm{Cs}$ are likely largely associated with albite and orthoclase, with neither mineral appreciably digested by aqua-regia. Thus, the overall rate of soil mineral weathering is not exhaustive, which appears reasonable given the soil's frigid temperature regime.

For the Padus pedons, $\mathrm{Li}, \mathrm{Na}, \mathrm{K}, \mathrm{Rb}$, and $\mathrm{Cs}$ ARD concentrations are comparatively greater in the deep and coarse-textured $2 \mathrm{C}$ horizons (Figure 1(a) and Figure 2(a)). Soil profile clay contents are less than five percent and uniform

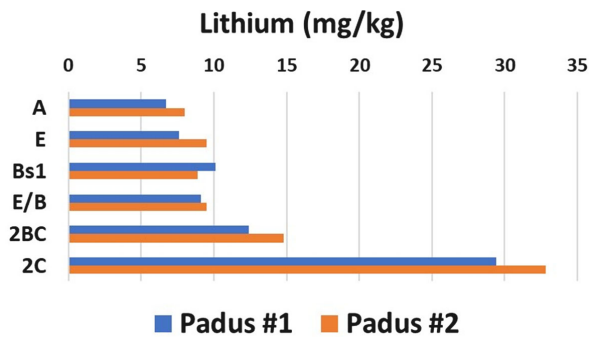

(a)

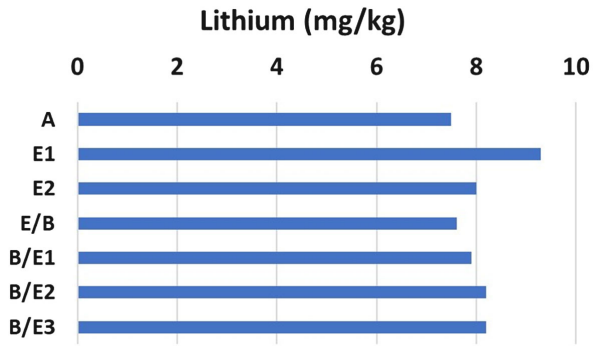

(b)

Figure 1. (a) Lithium (Li) aqua regia digestion concentrations for the Padus soil series; (b) Lithium ( $\mathrm{Li}$ ) aqua regia digestion concentrations for the Sporley-like soil series.

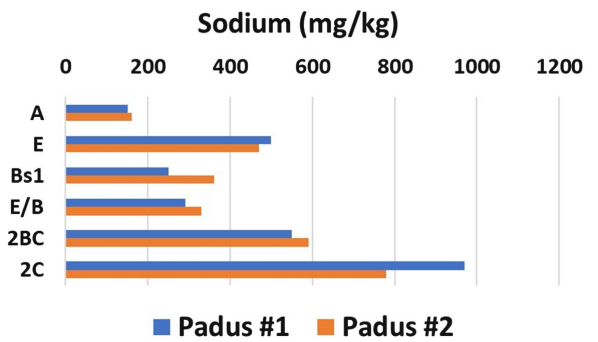

(a)

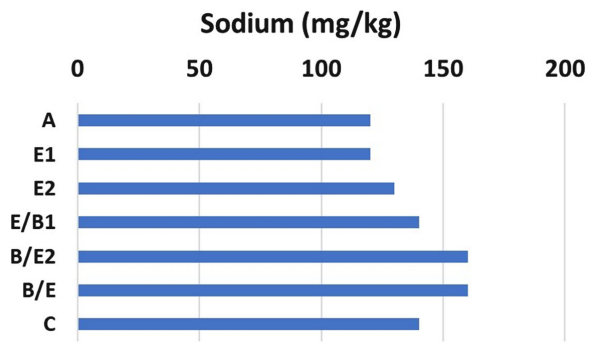

(b)

Figure 2. (a) Sodium (Na) aqua regia digestion concentrations for the Padus soil series; (b) Sodium $(\mathrm{Na})$ aqua regia digestion concentrations for the Sporley-like soil series. 
throughout each solum. Instrumental activation analysis does not indicate a greater pool of alkaline metals residing as crystalline lattice constituents in the 2C horizons. The downward percolation of soluble or organically complexed ARD alkali metals may be partially responsible for their greater presence below the lithologic discontinuity. The Sporley-like pedon has overall smaller alkali metal concentrations, a feature likely attributed to the Padus pedon developed in coarse-textured outwash, whereas the Sporley-like pedon was developed in silty-textured loess. The alkali metals in the Sporley-like pedon show a comparatively more uniform soil profile elemental distribution, possibly attributed to the reduced rate of water percolation and a greater clay content that provides an enhanced cation exchange capacity (Figure 1(b) and Figure 2(b)).

\subsection{Alkaline Earth Elements}

The alkaline earth elements are six elements in Group 2 (IIA) of the periodic table. Selecting calcium $(\mathrm{Ca})$ and barium $(\mathrm{Ba})$ as representative alkaline earth elements (Table 3 ), the concentration differences between the aqua regia digestion and the instrumental neutron activation analysis concentrations illustrate that the aqua regia digestion protocol incompletely recovered $\mathrm{Ca}$ and $\mathrm{Ba}$. Anorthoclase (Ca-bearing plagioclase mineral) is only partially digested by aqua regia digestion protocol and barite is not readily digested by aqua regia digestion protocol. Other alkaline earth bearing minerals have similar chemical reactivity and percentage recovery by the aqua regia digestion protocol.

Table 3. Concentration ( $\mathrm{mg} / \mathrm{kg}$ ) comparison of calcium (Ca) and Barium (Ba) from aqua-regia digestion (ARD) and Instrumental Neutron Activation Analysis (INAA).

\begin{tabular}{|c|c|c|c|c|}
\hline Horizon & Ca-ARD & Ca-INAA & Ba-ARD & Ba-INAA \\
\hline \multicolumn{5}{|l|}{ Padus \#1 } \\
\hline A & 1300 & 16,000 & 84 & 367 \\
\hline $\mathrm{E}$ & 900 & $<10,000$ & 54 & 612 \\
\hline Bs1 & 600 & 17,000 & 32 & 643 \\
\hline $\mathrm{E} / \mathrm{B}$ & 800 & 21,000 & 42 & 564 \\
\hline $\mathrm{BC}$ & 900 & 10,000 & 61 & 584 \\
\hline $2 \mathrm{C}$ & 1700 & 29,000 & 71 & 533 \\
\hline \multicolumn{5}{|l|}{ Padus \#2 } \\
\hline A & 1400 & $<10,000$ & 76 & 799 \\
\hline $\mathrm{E}$ & 1400 & $<10,000$ & 59 & 639 \\
\hline Bs 1 & 1200 & $<10,000$ & 41 & 623 \\
\hline $\mathrm{E} / \mathrm{B}$ & 1100 & $<10,000$ & 42 & 608 \\
\hline $\mathrm{BC}$ & 1200 & 14,000 & 54 & 609 \\
\hline $2 \mathrm{C}$ & 1900 & $<10,000$ & 108 & 733 \\
\hline
\end{tabular}


Both $\mathrm{Mg}$ and $\mathrm{Ca}$ are plant essential elements. For each of the pedons, ARD Mg shows increasing greater concentrations upon progression to deeper horizons (Figure 3(a) and Figure 3(b)). Base leaching is routinely associated with Spodosols. For the Sporley-like pedon, ARD Mg may be partially recovered from Mg-bearing phyllosilicates and the weathering of ferromagnesium amphiboles and pyroxenes, especially in the B/E horizons. For each of the pedons, ARD Ca shows concentration maxima in the A and E horizons, likely attributed to biocycling (Figure 4(a) and Figure 4(b)). Calcium also demonstrates ARD maxima

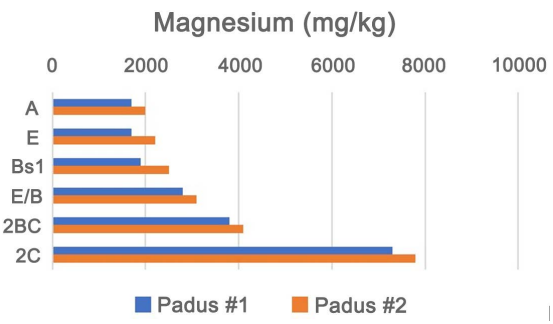

(a)

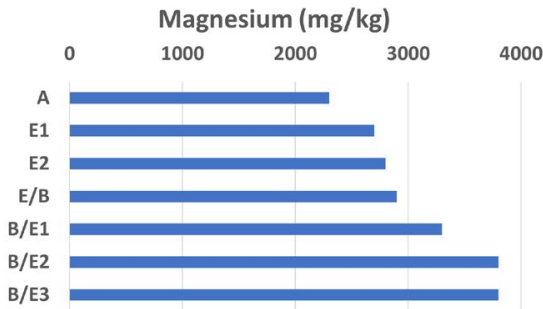

(b)

Figure 3. (a) Magnesium ( $\mathrm{Mg}$ ) aqua regia digestion concentrations for the Padus soil series; (b) Magnesium (Mg) aqua regia digestion concentrations for the Sporley-like soil series.

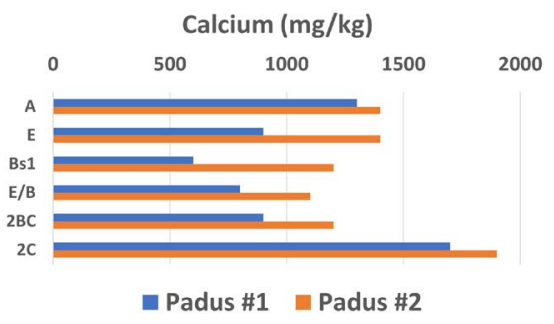

(a)

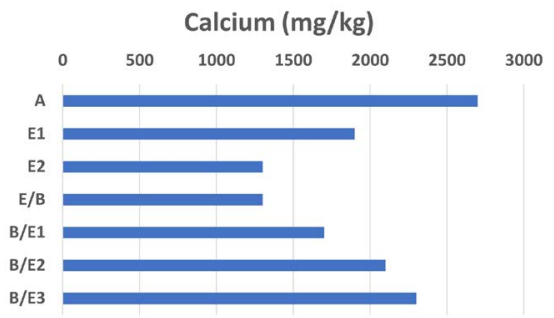

(b)

Figure 4. (a) Calcium (Ca) aqua regia digestion concentrations for the Padus soil series; (b) Calcium ( $\mathrm{Ca}$ ) aqua regia digestion concentrations for the Sporley-like soil series. 
below the lithologic discontinuity. Downward transport may be facilitated by fulvic acid and other organic acids. The chemical behavior of strontium ( $\mathrm{Sr}$ ) is similar to $\mathrm{Ca}$ and the soil profile $\mathrm{Ca}$ distribution patterns reflect the similar chemical reactivity (Figure 5(a) and Figure 5(b)). The soil profile distribution of $\mathrm{Ba}$ is similar to that of $\mathrm{Ca}$.

\subsection{Phosphorus and Sulfur}

Phosphorus (P) and sulfur ( $\mathrm{S}$ ) are plant essential elements. Phosphorus is widely understood to have a preferential adsorption affinity for Fe-oxides, especially in soils having an acidic reaction (Langmuir, 1997). In the Padus pedons, the ARD $\mathrm{P}$ exhibits two concentration maxima; that is, in the A horizon and more prominently below the lithologic discontinuity (Figure 6(a)). The P minimum concentration occurs in the Bs1 and E/B horizons. Given the small clay content, especially in the $2 \mathrm{C}$ horizons, the dominant mechanism for the $\mathrm{P}$ maxima below the lithologic discontinuity is likely the movement of $\mathrm{P}$ as an organic complex, whereas the maxima in the A horizon is likely biocycling resulting from forest floor enrichment (Fujinuma et al., 2005). The Sporley-like pedon exhibits $\mathrm{P}$ concentration enrichment in the A and E horizons (Figure 6(b)), also likely attributed to biocycling, whereas the increasing $\mathrm{P}$ enrichment of the $\mathrm{B} / \mathrm{E} 1$ to $\mathrm{B} / \mathrm{E} 3$ horizons is likely attributed to $\mathrm{P}$ leaching and subsequent adsorption on to $\mathrm{Fe}$-oxides associated with the clay separate or co-eluviation-illuviation of $\mathrm{P}$ with the Fe-oxide/clay separate.

Across all three pedons, $\mathrm{S}$ exhibits similar soil profile distribution to that of $\mathrm{P}$. The padus pedons show a greater partitioning in the upper-most $\mathrm{A}$ and $\mathrm{E}$ horizons, a feature attributed to biocycling. Sulfur enricment below the lithologic
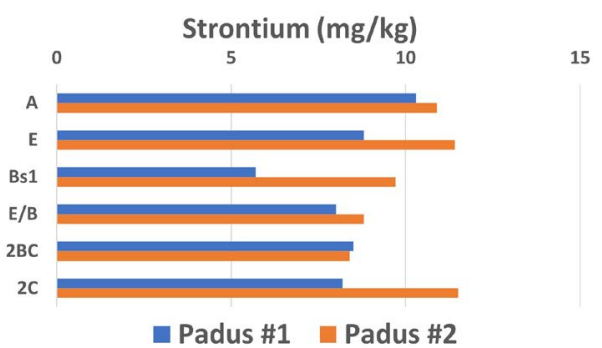

(a)

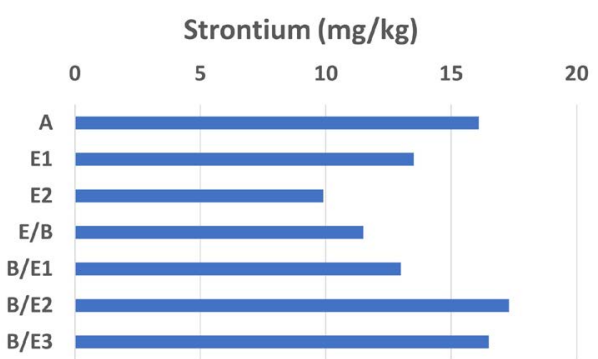

(b)

Figure 5. (a) Strontium (Sr) aqua regia digestion concentrations for the Padus soil series; (b) Strontium ( $\mathrm{Sr}$ ) aqua regia digestion concentrations for the Sporley-like soil series. 


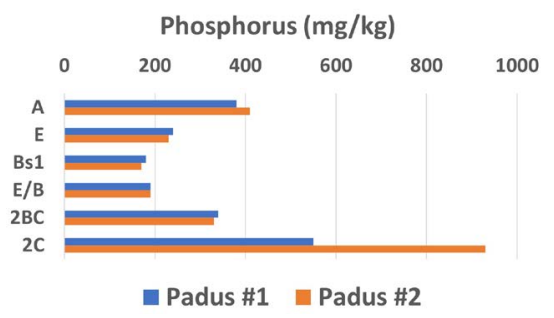

(a)

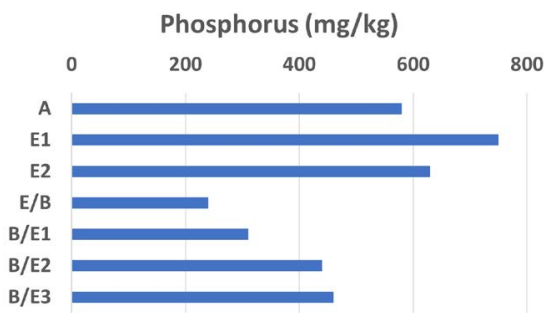

(b)

Figure 6. (a) Phosphorus (P) aqua regia digestion concentrations for the Padus soil series; (b) Phosphorus (P) aqua regia digestion concentrations for the Sporley-like soil series.

discontinuity is likely attributed to leaching and subsequent adsorption. Conversely, the Sporley-like pedon shows a pronounced S accumulation in the A horizon and no comparable accumulation in the deeper $\mathrm{B} / \mathrm{E} 1$ to $\mathrm{B} / \mathrm{E} 3$ horizons (Figure 7(a) and Figure 7(b)).

\subsection{Iron and Manganese, Other Transition Metals, Thorium and Uranium}

Except for contaminated soil, iron (Fe) and manganese $(\mathrm{Mn})$ are the two most abundant transition metals in the soil environment. Both $\mathrm{Fe}$ and $\mathrm{Mn}$ are considered plant essential elements. As with the alkali metals and the alkaline earth elements, the INAA analysis provided significantly greater Fe and Mn concentrations than the aqua regia digestion protocol (Fe shown in Table 4).

The aqua regia digestion $\mathrm{Fe}$ concentrations of the Padus pedons demonstrate an increasing concentration recovery from the A through the Bs1 horizon and continuing through to the $2 \mathrm{C}$ horizons (Figure 8(a)). Given the small clay contents of the $\mathrm{BC}$ and $2 \mathrm{C}$ horizons and the greater Fe concentrations observed in these horizons, the soil profile Fe distribution pattern is not entirely attributed to $\mathrm{Fe}$ adsorption onto phyllosilicates with subsequent co-Fe-clay eluviation-illuviation. One possible soil process supported by the $\mathrm{Fe}$ soil profile distribution is $\mathrm{Fe}$-organic acid complexation with subsequent placement in the deeper soil horizons attributed to $\mathrm{pH}$ differences and increasing $\mathrm{Fe}$ concentrations fostering Fe-complex sorption/precipitation. The Sporley-like pedon's aqua regia digestion $\mathrm{Fe}$ concentrations demonstrate an increasing concentration recovery from the $\mathrm{A}$ through the $\mathrm{B} / \mathrm{E} 1$ to $\mathrm{B} / \mathrm{E} 3$ horizons (Figure $8(\mathrm{~b})$ ). The Fe concentrations in the $\mathrm{B} / \mathrm{E} 1$ to $\mathrm{B} / \mathrm{E} 3$ soil horizons are similar, suggesting that the greater clay contents provide greater surface area for Fe-organic complex adsorption/precipitation. 


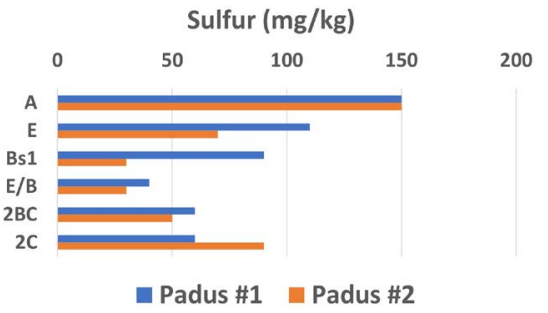

(a)

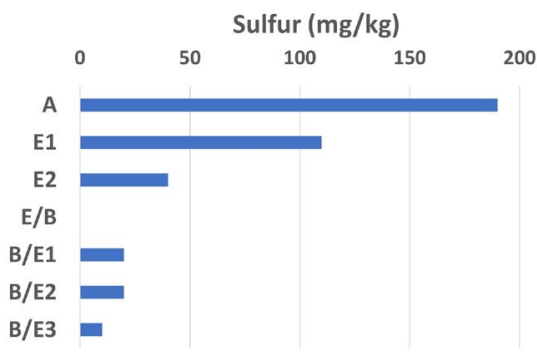

(b)

Figure 7. (a) Sulfur (S) aqua regia digestion concentrations for the Padus soil series; (b) Sulfur (S) aqua regia digestion concentrations for the Sporley-like soil series.

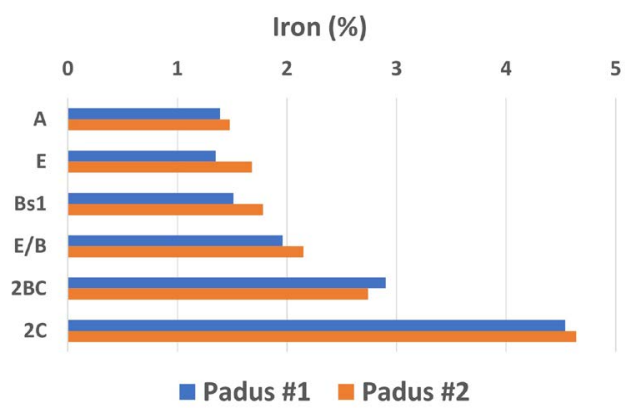

(a)

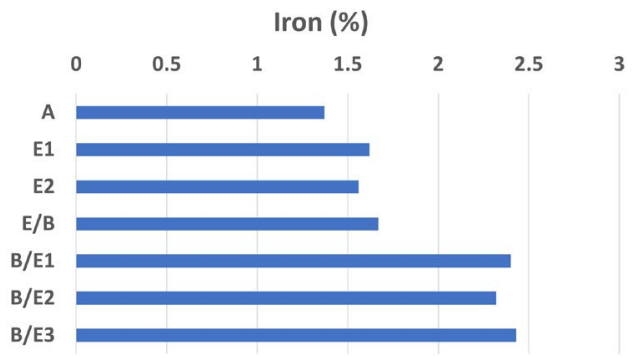

(b)

Figure 8. (a) Iron ( $\mathrm{Fe}$ ) aqua regia digestion concentrations for the Padus soil series; (b) Iron $(\mathrm{Fe})$ aqua regia digestion concentrations for the Sporley-like soil series.

For the Padus pedon's and the Sporley-like pedon, Mn concentrations show $\mathrm{Mn}$ accumulation in the A horizon, a minimum in the Bs1-E/B horizons and increasingly greater $\mathrm{Mn}$ concentrations in the deeper 2C horizons (Figure 9(a) and Figure 9(b)). Bioaccumulation in the A horizons and leaching, possibly assisted by organic complexation, with subsequent Mn-oxide formation in the deeper soil horizons are potentially active soil processes. 
Table 4. Concentration ( $\mathrm{mg} / \mathrm{kg}$ ) comparison of iron (Fe), chromium $(\mathrm{Cr})$ and Zinc $(\mathrm{Zn})$ from aqua-regia digestion (ARD) and Instrumental Neutron Activation Analysis (INAA).

\begin{tabular}{ccccccc}
\hline Horizon & Fe-ARD & Fe-INAA & Cr-ARD & Cr-INAA & Zn-ARD & Zn-INAA \\
\hline Padus \#1 & & & & & & \\
A & 13,900 & 26,000 & 16 & 493 & 44.6 & 168 \\
E & 13,500 & 20,000 & 15 & 313 & 34.0 & 174 \\
Bs1 & 15,100 & 27,000 & 16 & 183 & 31.2 & 96 \\
E/B & 19,600 & 26,000 & 24 & 247 & 28.5 & 63 \\
BC & 29,000 & 32,000 & 35 & 386 & 33.5 & 109 \\
2C & 45,400 & 37,000 & 48 & 526 & 50.5 & $<50$ \\
Padus \#2 & & & & & & \\
A & 14,800 & 24,000 & 16 & 450 & 69.2 & 99 \\
E & 16,800 & 27,000 & 19 & 438 & 36.0 & 73 \\
Bs1 & 17,800 & 28,000 & 21 & 460 & 28.8 & 80 \\
E/B & 21,500 & 31,000 & 25 & 288 & 28.3 & 136 \\
BC & 27,400 & 38,000 & 32 & 417 & 34.6 & $<50$ \\
2C & 46,400 & 32,000 & 58 & 583 & 63.8 & $<50$ \\
\hline
\end{tabular}

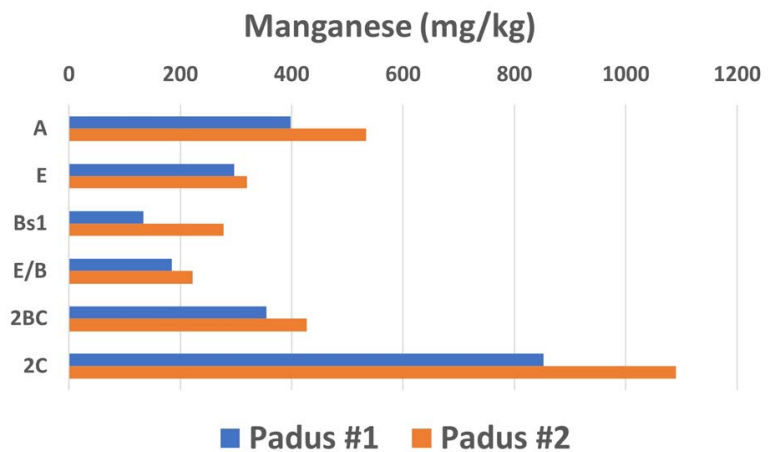

(a)

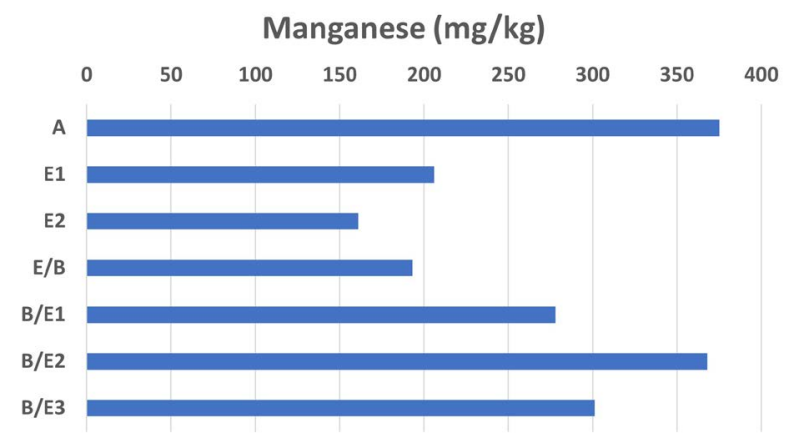

(b)

Figure 9. (a) Manganese (Mn) aqua regia digestion concentrations for the Padus soil series; (b) Manganese (Mn) aqua regia digestion concentrations for the Sporley-like soil series. 
Most transition metals demonstrate a soil profile distribution like Fe; that is, the transition metals exhibit increasingly greater concentrations on transition to the deeper soil horizons, with little evidence of substantial A horizon enrichment. Other transition metals, like Mn, exhibit a bimodal soil profile distribution where the two maxima occur in the A horizon and below the lithologic discontinuity. As an example, copper $(\mathrm{Cu})$ exhibits a soil profile distribution like $\mathrm{Fe}$ in the Padus and Sporley-like pedons (Figure 10(a) and Figure 10(b)). Conversely, zinc ( $\mathrm{Zn})$ exhibits a soil profile distribution like $\mathrm{Mn}$ in the Padus and Sporley-like pedons (Figure 11(a) and Figure 11(b)). Lead $(\mathrm{Pb})$ demonstrates a soil profile distribution like to $\mathrm{Mn}$, with appreciable A horizon enrichment (Figure 12(a) and Figure 12(b)). Lead is frequently cited as having a strong sorption affinity towards soil organic matter (Kabata-Pendias, 2011). Pearson correlation shows that the soil profile distributions of Scandium (Sc), Titanium (Ti), Vanadium $(\mathrm{V})$, chromium $(\mathrm{Cr})$, nickel $(\mathrm{Ni})$, copper $(\mathrm{Cu})$, Yttrium $(\mathrm{Y})$, Lanthanum (La), Thorium (Th) and Uranium (U) are like the observed Fe soil profile distributions (Table 5).

In general, thorium (Th) and uranium (U) exhibit greater INAA concentrations than the aqua regia digestion protocol (Table 6). Table 7(a) and Table 7(b) list the minimum, mean, standard deviation, and maximum concentrations $(\mathrm{mg} / \mathrm{kg})$ for selected transition metals, metalloids, Th, and $\mathrm{U}$ derived from an aqua regia digestion protocol for the Padus and Sporley-like pedons, respectively. The soil profile distribution of the aqua regia digestion concentrations for Th

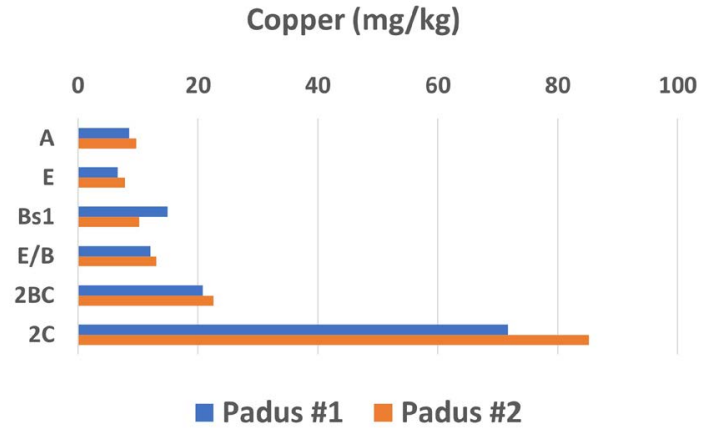

(a)

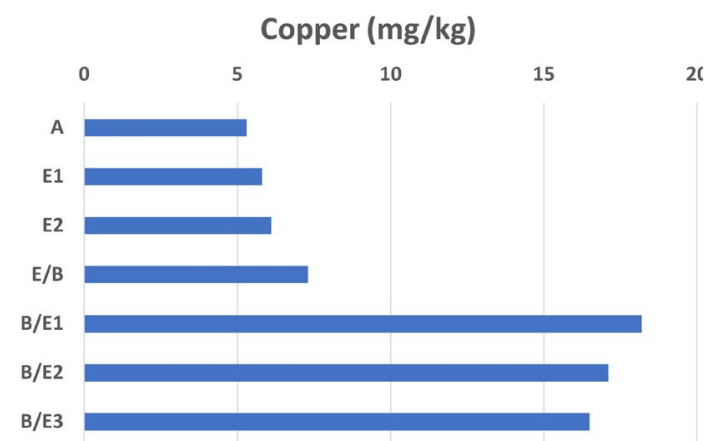

(b)

Figure 10. (a) Copper $(\mathrm{Cu})$ aqua regia digestion concentrations for the Padus soil series; (b) Copper $(\mathrm{Cu})$ aqua regia digestion concentrations for the Sporley-like soil series. 


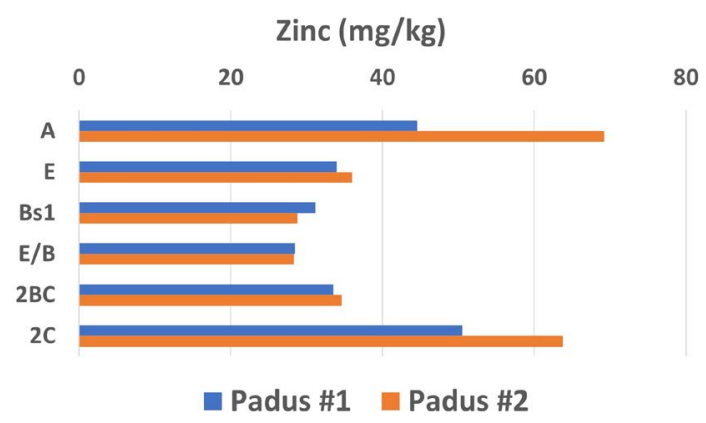

(a)

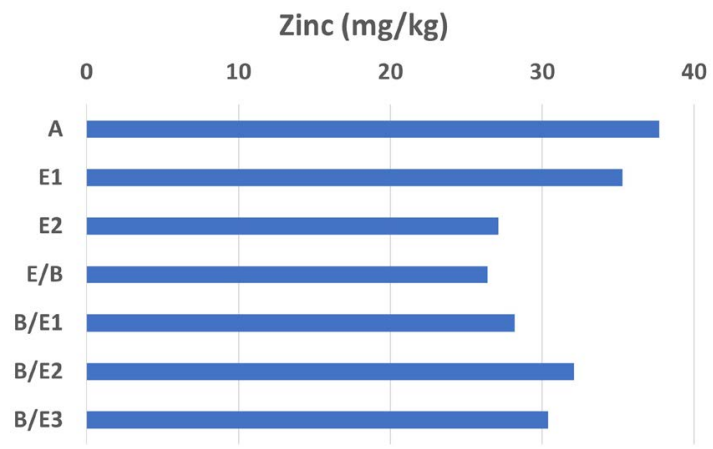

(b)

Figure 11. (a) Zinc (Zn) aqua regia digestion concentrations for the Padus soil series; (b) $\mathrm{Zinc}(\mathrm{Zn})$ aqua regia digestion concentrations for the Sporley-like soil series.

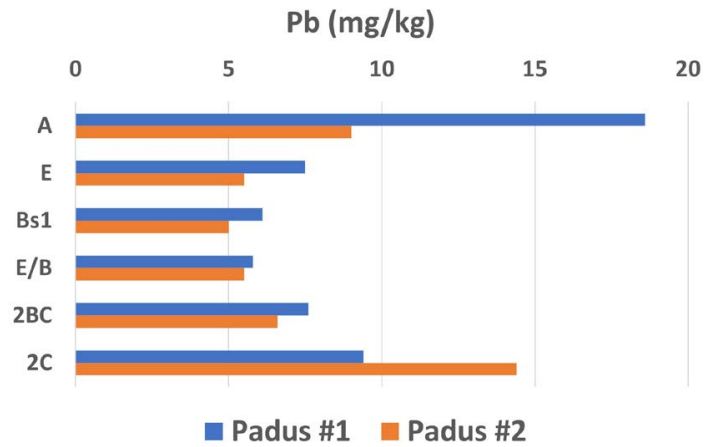

(a)

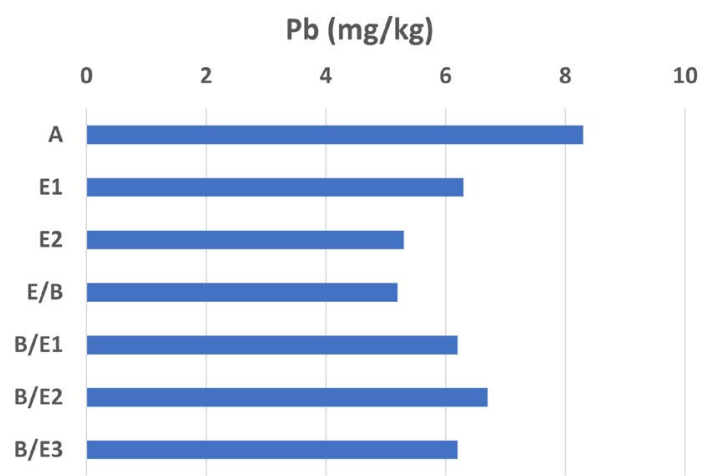

(b)

Figure 12. (a) Lead $(\mathrm{Pb})$ aqua regia digestion concentrations for the Padus soil series; (b) lead $(\mathrm{Pb})$ aqua regia digestion concentrations for the Sporley-like soil series. 
Table 5. Regression equations involving transition metals, Th and $U$ (dependent variable as $\mathrm{mg} / \mathrm{kg}$ ) and iron (Fe as Independent Variable as percent) derived from an aqua regia digestion.

\begin{tabular}{cccc}
\hline Transition Metal & Slope & Intercept & R2 \\
\hline Scandium (Sc) & 1.97 & -1.62 & 0.993 \\
Titanium (Ti) & 0.02 & +0.04 & 0.849 \\
Vanadium (V) & 20.36 & 0.0 & 0.997 \\
Chromium (Cr) & 11.70 & 0.0 & 0.996 \\
Nickel (Ni) & 9.97 & -6.35 & 0.936 \\
Copper (Cu) & 21.33 & -27.65 & 0.904 \\
Zinc (Zn) & 5.05 & 25.83 & 0.164 \\
Yttrium (Y) & 3.12 & -1.32 & 0.73 \\
Lanthanum (La) & 5.92 & 4.16 & 0.841 \\
Thorium (Th) & 1.88 & -0.15 & 0.756 \\
Uranium (U) & 0.38 & -0.08 & 0.942
\end{tabular}

Table 6. Concentration (mg/kg) comparison of Thorium (Th) and Uranium (U) from aqua-regia digestion (ARD) and Instrumental Neutron Activation Analysis (INAA).

\begin{tabular}{ccccc}
\hline Horizon & Th-ARD & Th-INAA & U-ARD & U-INAA \\
\hline Padus \#1 & & & & \\
A & 1.9 & 5.8 & 0.5 & 2.1 \\
E & 1.8 & 6.7 & 0.4 & 1.6 \\
Bs1 & 2.0 & 5.3 & 0.5 & 2.2 \\
E/B & 4.2 & 8.1 & 0.7 & 1.4 \\
BC & 5.7 & 5.3 & 1.0 & 1.1 \\
2C & 6.4 & 5.2 & 1.5 & 2.1 \\
Padus \#2 & & & & \\
A & 1.6 & 5.2 & 0.4 & 3.4 \\
E & 2.4 & 8.1 & 0.5 & 2.9 \\
Bs1 & 3.6 & 6.6 & 0.6 & 2.0 \\
E/B & 4.2 & 4.8 & 0.7 & 0.7 \\
BC & 5.8 & 6.7 & 0.8 & 1.3 \\
2C & 8.5 & 1.7 & 1.9 & 3.1 \\
\hline
\end{tabular}

Table 7. (a) Transition metals, metalloid, Th and U concentration data ( $\mathrm{mg} / \mathrm{kg}$ ) derived from an aqua regia digestion for the Padus pedons; (b) Transition metals, metalloid, Th and $U$ concentration data $(\mathrm{mg} / \mathrm{kg})$ derived from an aqua regia digestion for the Sporley-like pedons.

(a)

\begin{tabular}{cccccc}
\hline Element & Minimum & Mean & STD & Maximum & Trend \\
\hline Iron (Fe) & 13,500 & 23,400 & 11,600 & 46,400 & - \\
Manganese (Mn) & 134 & 424 & 281 & 1090 & - \\
Cobalt (Co) & 3.5 & 7.9 & 5.9 & 21.8 & $\mathrm{Fe}$ \\
\hline
\end{tabular}




\section{Continued}

\begin{tabular}{cccccc}
\hline Scandium (Sc) & 1.1 & 2.8 & 2.3 & 7.6 & $\mathrm{Fe}$ \\
Titanium (Ti) & 0.06 & 0.09 & 0.03 & 0.4 & $\mathrm{Fe}$ \\
Vanadium (V) & 29 & 47.5 & 21.3 & 90 & $\mathrm{Fe}$ \\
Chromium (Cr) & 15 & 27 & 14 & 58 & $\mathrm{Fe}$ \\
Nickel (Ni) & 6.7 & 16.9 & 12.4 & 46.1 & $\mathrm{Fe}$ \\
Copper (Cu) & 6.6 & 23.6 & 26.2 & 85.2 & $\mathrm{Fe}$ \\
Zinc (Zn) & 28.3 & 40.3 & 13.9 & 69.2 & $\mathrm{Mn}$ \\
Yttium (Y) & 2.5 & 5.0 & 3.9 & 14.7 & $\mathrm{Fe}$ \\
Zirconium (Zr) & 0.2 & 2.3 & 2.1 & 6.5 & $\mathrm{Fe}$ \\
Gallium (Ga) & 3.2 & 4.3 & 1.6 & 8.3 & $\mathrm{Fe}$ \\
Arsenic (As) & 0.9 & 6.0 & 7.8 & 23.3 & $\mathrm{Fe}$ \\
Selenium (Se) & 0.4 & 0.55 & 0.12 & 0.8 & $\mathrm{Uniform}$ \\
Tin (Sn) & 0.48 & 2.25 & 3.67 & 10.8 & $\mathrm{Mn}$ \\
Bismuth (Bi) & 0.08 & 0.14 & 0.08 & 0.34 & Uniform \\
Antimony (Sb) & 0.08 & 0.20 & 0.13 & 0.48 & $\mathrm{Fe}$ \\
Lead (Pb) & 5.0 & 8.4 & 4.1 & 18.6 & $\mathrm{Mn}$ \\
Lanthanum (La) & 11.8 & 17.0 & 7.5 & 35.6 & $\mathrm{Fe}$ \\
Thorium (Th) & 1.6 & 4.0 & 2.2 & 8.5 & $\mathrm{Fe}$ \\
Uranium (U) & 0.4 & 0.8 & 0.5 & 1.9 & $\mathrm{Fe}$ \\
\hline
\end{tabular}

STD is the standard deviation, Trend is a significant correction with either Fe or Mn, whereas "uniform" implies there is little variance across the soil profile.

(b)

\begin{tabular}{cccccc}
\hline Element & Minimum & Mean & STD & Maximum & Trend \\
\hline Iron (Fe) & 13,700 & 19,100 & 4,540 & 24,300 & - \\
Manganese (Mn) & 161 & 269 & 85 & 375 & - \\
Cobalt (Co) & 4.0 & 6.0 & 1.5 & 7.6 & $\mathrm{Fe}$ \\
Scandium (Sc) & 1.1 & 2.5 & 1.4 & 4.1 & $\mathrm{Fe}$ \\
Titanium (Ti) & 0.06 & 0.09 & 0.02 & 0.1 & $\mathrm{Fe}$ \\
Vanadium (V) & 27.0 & 40.9 & 11.0 & 54.0 & $\mathrm{Fe}$ \\
Chromium (Cr) & 16 & 23 & 5 & 29 & $\mathrm{Fe}$ \\
Nickel (Ni) & 8.7 & 12.9 & 2.8 & 16.4 & $\mathrm{Fe}$ \\
Copper (Cu) & 5.3 & 10.9 & 6.0 & 18.2 & $\mathrm{Fe}$ \\
Zinc (Zn) & 26.4 & 31.0 & 4.3 & 37.7 & $\mathrm{Mn}$ \\
Yttium (Y) & 3.5 & 6.3 & 2.9 & 10.2 & $\mathrm{Fe}$ \\
Zirconium (Zr) & 0.3 & 5.0 & 5.0 & 12.0 & $\mathrm{Fe}$ \\
Gallium (Ga) & 3.1 & 3.6 & 0.5 & 4.1 & $\mathrm{Fe}$ \\
Arsenic (As) & 1.3 & 2.7 & 1.3 & 4.1 & $\mathrm{Fe}$ \\
Selenium (Se) & 0.3 & 0.4 & 0.1 & 0.6 & $\mathrm{Uniform}$ \\
Tin (Sn) & 0.39 & 0.46 & 0.07 & 0.53 & $\mathrm{Fe}$ \\
Bismuth (Bi) & 0.07 & 0.09 & 0.02 & 0.12 & $\mathrm{Uniform}$ \\
\hline
\end{tabular}


Continued

\begin{tabular}{cccccc}
\hline Antimony $(\mathrm{Sb})$ & 0.11 & 0.17 & 0.06 & 0.24 & $\mathrm{Fe}$ \\
Lead $(\mathrm{Pb})$ & 5.2 & 6.3 & 1.0 & 8.3 & $\mathrm{Mn}$ \\
Lanthanum $(\mathrm{La})$ & 13.1 & 17.2 & 3.7 & 21.9 & $\mathrm{Fe}$ \\
Thorium (Th) & 0.9 & 3.8 & 2.0 & 5.8 & $\mathrm{Fe}$ \\
Uranium (U) & 0.50 & 0.69 & 0.16 & 0.90 & $\mathrm{Fe}$ \\
\hline
\end{tabular}

STD is the standard deviation. Trend is a significant correction with either Fe or Mn, whereas "uniform" implies there is little variance across the soil profile.

and $\mathrm{U}$ show increasing concentrations on progression from the A horizons to the deeper soil horizons, a feature that parallels the soil profile distribution concentrations of Fe. There is little evidence for A horizon enrichment of Th and $\mathrm{U}$ because of biocycling by the forest vegetation.

The transition metals, metalloids, Th, and $\mathrm{U}$ concentrations derived from an aqua regia digestion protocol for the Padus pedons and the Sporley-like pedon (Table 7(a) and Table 7(b)) are typical for soils as documented in Kabata-Pendias (2011). In the Padus pedons, Fe ranges from a minimum of 13,500 $\mathrm{mg} / \mathrm{kg}$ to a maximum of $46,400 \mathrm{mg} / \mathrm{kg}$, whereas the Sporley-like pedon has a smaller Fe concentration range, ranging from a minimum of $13,700 \mathrm{mg} / \mathrm{kg}$ to a maximum of $24,300 \mathrm{mg} / \mathrm{kg}$. The manganese concentration ranges between the Padus pedons and the Sporley-like pedons are comparable (Table 7(a) and Table 7(b)).

\subsection{Rare Earth Elements}

The rare earth elements (REE) are the 14 elements comprising the Lanthanide Series: cerium $(\mathrm{Ce})$, praseodymium $(\mathrm{Pr})$, neodymium $(\mathrm{Nd})$, promethium $(\mathrm{Pm})$, samarium $(\mathrm{Sm})$, europium $(\mathrm{Eu})$, gadolinium $(\mathrm{Gd})$, terbium $(\mathrm{Tb})$, dysprosium (Dy), holmium (Ho), erbium (Er), thulium (Tm), ytterbium ( $\mathrm{Yb}$ ), and lutetium $(\mathrm{Lu})$. The Lanthanide Series are elements characterized as having one or more electrons in $4 \mathrm{f}$ electronic orbitals. The normally trivalent REE elements have considerable ionic bonding character.

The light rare earth elements (LREE) are comprised of the elements La to Eu and the heavy rare earth elements (HREE) are comprised of the elements Gd to $\mathrm{Lu}$. The REE concentration differences between the INAA and aqua regia digestion protocol is comparatively small for the LREE's and somewhat greater for the HREE's. In many soils, aqua regia digestion resistant zircon is the dominant HREE-bearing mineral, whereas the more aqua regia digestible mineral apatite is likely the dominant LREE-bearing mineral (Aide and Aide, 2012; Aide, 2018).

For all pedons, the LREE's exhibit greater abundances than the HREE's, a feature attributed to the greater abundance of LREE-bearing minerals and the more efficient aqua regia digestion recovery of the LREE's (Table 8). Each of the 14 REE's exhibit greater concentrations on progression from the A horizon through the Bs horizon to the deeper $2 \mathrm{C}$ (Padus) or B/E horizons (Sporley-like pedon) (Figures 13(a)-(c)). The pH dependent mobility of the REE's in soil has been 


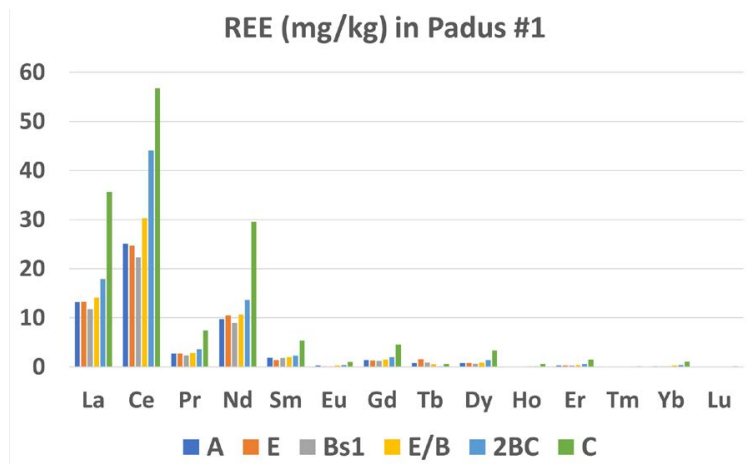

(a)

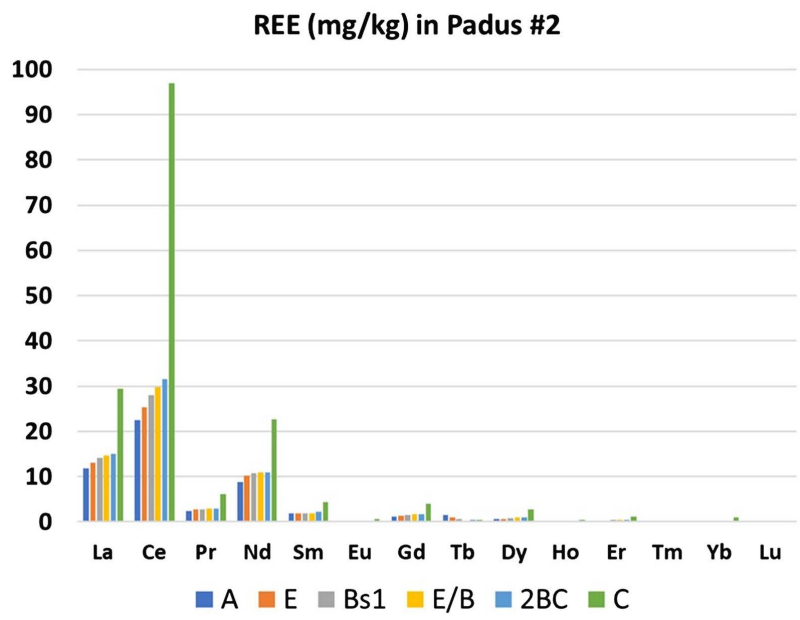

(b)

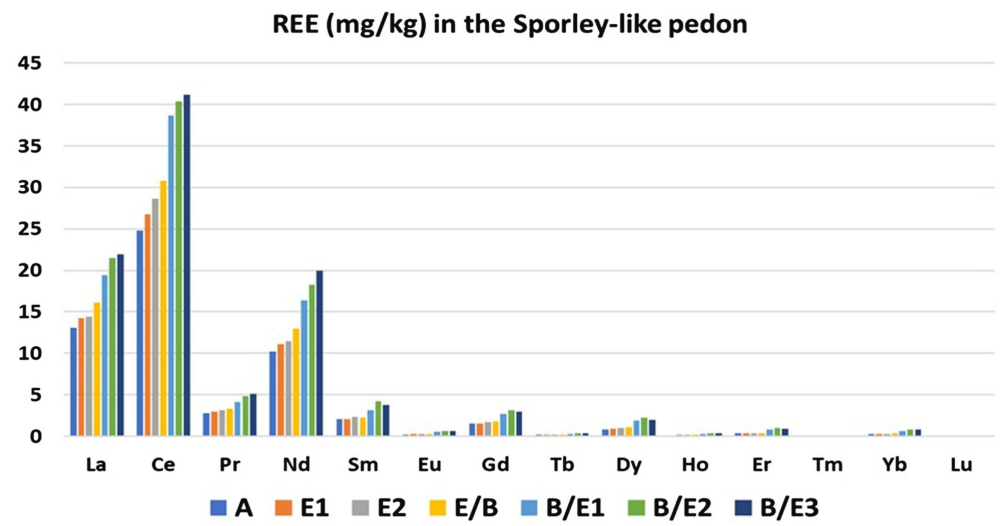

(c)

Figure 13. (a) Rare earth elements (REE) aqua regia digestion concentrations for the Padus \#1 soil series; (b) Rare earth elements (REE) aqua regia digestion concentrations for the Padus \#2 soil series; (c) Rare earth elements (REE) aqua regia digestion concentrations for the Sporley-like soil series.

documented (Aide and Smith-Aide, 2003; Aide et al., 2011; Aide and Aide, 2012; Aide, 2018; Brown et al., 2003). The REE's have been documented to be 1) complexed with soil organic matter, especially fulvic acids, 2) exist as inner-sphere complexes with phyllosilicates, and 3) form strong inorganic ionic pair mono and di-complexes with carbonate anions (Aide, 2018). 
Table 8. Concentration ( $\mathrm{mg} / \mathrm{kg}$ ) comparison of Lanthanum (La), Samarium (Sm), and Ytterbium $(\mathrm{Yb})$ from aqua-regia digestion $(\mathrm{ARD})$ and Instrumental Neutron Activation Analysis (INAA).

\begin{tabular}{ccccccc}
\hline Horizon & La-ARD & La-INAA & Sm-ARD & Sm-INAA & Yb-ARD & Yb-INAA \\
\hline Padus \#1 & & & & & & \\
A & 13.2 & 16 & 1.9 & 2.6 & 0.2 & 2.5 \\
E & 13.3 & 18 & 1.4 & 3.0 & 0.2 & 2.6 \\
Bs1 & 11.8 & 19 & 1.8 & 3.1 & 0.2 & 1.9 \\
E/B & 14.1 & 20 & 2.0 & 3.2 & 0.3 & 2.8 \\
BC & 17.9 & 17 & 2.3 & 3.0 & 0.4 & 1.5 \\
2C & 35.6 & 22 & 5.4 & 3.7 & 1.1 & 1.1 \\
Padus \#2 & & & & & & \\
A & 11.8 & 18 & 1.9 & 2.8 & 0.2 & 2.2 \\
E & 13.1 & 19 & 1.9 & 2.9 & 0.2 & 2.0 \\
Bs1 & 14.2 & 20 & 1.9 & 3.0 & 0.3 & 1.6 \\
E/B & 14.6 & 20 & 1.9 & 3.2 & 0.3 & 2.2 \\
BC & 15.0 & 19 & 2.3 & 3.0 & 0.3 & 1.8 \\
2C & 29.4 & 16 & 4.4 & 2.8 & 0.9 & 1.8 \\
\hline
\end{tabular}

\section{Employment of an Aqua Regia Digestion Protocol to Assess the Intensity of Pedogenic Pathways}

The chosen pedons represent soils that possess both spodic and alfic characteristics. The intent of the manuscript is to determine the effectiveness of a simple aqua regia digestion protocol to infer the presence and qualitatively gauge the intensity of pedogenic pathways. The pedogenic pathways integral to spodic and alfic sequum's include: 1) lessivage, 2) biocycling, 3) eluviation-illuviation of organic-metal complexes. Elements that exhibit enhanced concentrations in the A horizon, presumably because of biocycling or a preferential and intense sorption capacity with soil organic matter, include: $\mathrm{Ca}, \mathrm{Sr}, \mathrm{Ba}, \mathrm{P}, \mathrm{S}, \mathrm{Mn}, \mathrm{Zn}, \mathrm{Sn}$ and $\mathrm{Pb}$. Elements that exhibit enhanced concentrations with increasing soil depth include: the alkali metals, the alkaline earths, most of the transition metals, the rare earth elements, Th and $\mathrm{U}$. The dominant transport mechanisms are soluble organic metal complexes and co-illuviation with Fe-oxyhydroxides or phyllosilicates. Thus, the aqua regia digestion protocol revealed concentration differences supporting these are actively occurring pedogenic pathways.

Advantages accrued to the field morphologist include: 1) additional data to make soil evolution judgements, 2) a reconnaissance survey to detect anthropogenic impact from heavy metals, and 3) low cost. Disadvantages include: a near total elemental appraisal does not provide quantitative data specific to a given pedogenic pathway, 4) data interpretation relies on the expertise of the soil morphologist, 5) lithologic discontinuities present element concentration dif- 
ferences that may be geologic rather than pedogenic, 6) soil amendments may promote "relative elemental abundances" that are not pedogenic. For clinical practice, elemental analysis may reveal pedogenic pathway differences when applied to landscapes where variation of only one soil forming factor dominates, such as a toposequence.

\section{Acknowledgements}

The authors wish to thank Southeast Missouri State University for support of this research.

\section{Conflicts of Interest}

The authors declare no conflicts of interest regarding the publication of this paper.

\section{References}

Aide, M. T. (2018). Lanthanide Soil Chemistry and Its Importance in Understanding Soil Pathways: Mobility, Plant Uptake and Soil Health. In Lanthanides (pp. 49-65). Rijeka: InTech. https://doi.org/10.5772/intechopen.79238

Aide, M. T., \& Aide, C. C. (2012). Rare Earth Elements: Their Importance in Understanding Soil Genesis. International Scholarly Research Network ISRN Soil Science, 2012, Article ID: 783876. https://doi.org/10.5402/2012/783876

Aide, M. T., \& Braden, I. (2009). Inter-Horizon Transport of Elements in Ultisols Developed in a Loess Mantle Mixed with Rhyolite Residuum in the St. Francois Mountains of Missouri. Soil Science, 174, 210-219. https://doi.org/10.1097/SS.0b013e31819cd232

Aide, M. T., \& Fasnacht, M. (2010). Estimating Trace Element Availability in Soils Having a Seasonal Water Table Using Commercially Available Protocols. Communications in Soil Science and Plant Analysis, 41, 1159-1177. https://doi.org/10.1080/00103621003721379

Aide, M. T., \& Pavich, Z. (2002). Rare Earth Element Mobilization and Migration in a Wisconsin Spodosols. Soil Science, 167, 680-691. https://doi.org/10.1097/00010694-200210000-00006

Aide, M. T., \& Smith-Aide, C. (2003). Assessing Soil Genesis Using Rare Earth Element Analysis. Soil Science Society of America Journal, 67, 1470-1476. https://doi.org/10.2136/sssaj2003.1470

Aide, M. T., Braden, I., Hermann, N., Mauk, D., Mueller, W., Svenson, S., \& Weathers, J. (2011). Using Lanthanum, Neodymium, and Thorium as Conservative Indexing Elements to Indicate Soil Lead Deposition. Soil and Soil Contamination, 22, 132-150. https://doi.org/10.1080/15320383.2013.722136

Alfassi, Z. B. (1994). Chemical Analysis by Nuclear Methods. Hoboken, NJ: John Wiley and Sons, Inc.

Bazilevskaya, E., Archibald, D. D., \& Martinez, C. E. (2018). Mineral Colloids Mediate Organic Carbon Accumulation in a Temperate Forest Spodosol: Depth-Wise Changes in Pore Water Chemistry. Biogeochemistry, 141, 75-94.

https://doi.org/10.1007/s10533-018-0504-4

Bockheim, J. G. (2003). Genesis of Bisequal Soils on Acidic Drift in the Upper Great Lakes Region, USA. Soil Science Society of America Journal, 67, 612-619. 
https://doi.org/10.2136/sssaj2003.6120

Bockheim, J. G., \& Hartemink, A. E. (2016). The Soils of Wisconsin. Berlin: Springer International Publishing. https://doi.org/10.1007/978-3-319-52144-2

Bockheim, J. G., \& Jordan, J. (2004). Soils of the Sylvania Wilderness-Recreation Area, Western Upper Peninsula, Michigan. USDA-Forest Service, North Central Research Station, General Technical Report NC-237. https://doi.org/10.2737/NC-GTR-237

Brown, D. J., Helmke, P. A., \& Clayton, M. K. (2003). Robust Geochemical Indices for Redox and Weathering on a Granitic Laterite Landscape in Central Uganda. Geochimica et Cosmochimica Acta, 67, 2711-2723. https://doi.org/10.1016/S0016-7037(03)00104-2

Browne, B. A. (1995). Toward a New Theory of Podzolization. In W. W. McFee, \& J. M. Kelly (Ed.), Carbon Forms and Functions in Forest Soils (pp. 253-273). Madison, WI: Soil Science, Soc. Am. https://doi.org/10.2136/1995.carbonforms.c12

Buol, S. W., \& Hole, F. D. (1959). Some Characteristics of Clay Skins on Peds in the B Horizon of a Gray-Brown Podzolic Soil. Soil Science Society of America, Proceedings, 23, 239-241. https://doi.org/10.2136/sssaj1959.03615995002300030025x

Buol, S. W., Hole, F. D., McCracken, R. J., \& Southard, R. J. (2003). Soil Genesis and Classification. Ames, IA: Iowa State Univ. Press.

Carter, M. R. (1993). Soil Sampling and Methods of Analysis. Boca Raton, Fl: Lewis Publ.

Clayton, L., Attig, J. W., \& Mickelson, D. M. (2001). Effects of Late Pleistocene Permafrost on the Landscape of Wisconsin, USA. Boreas, 30, 173-188. https://doi.org/10.1080/030094801750424111

Fujinuma, R., Bockheim, J., \& Balster, N. (2005). Base-Cation Cycling by Individual Tree Species in Old-Growth Forests of Upper Michigan, USA. Biogeochemistry, 74, 357-376. https://doi.org/10.1007/s10533-004-4726-2

Hole, F. D. (1975). Some Relationships between Forest Vegetation and Podzol B Horizons in Soils of Menominee Tribal Lands, Wisconsin, USA. Soviet Soil Science, 7, 714-723.

Kabata-Pendias, A. (2011). Trace Elements in Soils and Plants (4th ed.). Boca Raton, FL: CRC Press. https://doi.org/10.1201/b10158

Langmuir, D. (1997). Aqueous Environmental Geochemistry. Upper Saddle River, NJ: Prentiss-Hall.

Madison, F. W., \& Lee, G. B. (1965). Some Mineralogic Characteristics of Sandy Soils in Wisconsin. Wisconsin Academy Sciences Arts Letters Transactions, 54, 223-230.

Moore, D. M., \& Reynolds, R. C. (1989). X-Ray Diffraction and the Identification and Analysis of Clay Minerals. Oxford: Oxford University Press.

Richardson, J. L., \& Hole, F. D. (1979). Mottling and Iron Distribution in a Glossoboralf-Haplaquoll Hydrosequence on a Glacial Moraine in Northwestern Wisconsin. Soil Science Society of America Journal, 43, 552-558. https://doi.org/10.2136/sssaj1979.03615995004300030024x

Schaetzl, R. J., \& Isard, S. A. (1996). Regional-Scale Relationships between Climate and Strength of Podzolization in the Great Lakes Region, North America. Catena, 28, 47-69. https://doi.org/10.1016/S0341-8162(96)00029-X

Webb, T. (1974). A Vegetational History from Northern Wisconsin: Evidence from Modern and Fossil Pollen. The American Midland Naturalist, 92, 12-34. https://doi.org/10.2307/2424199

White, A. F. (1995). Chemical Weathering Rates of Silicate Minerals in Soil. In White and Brantley (Eds.), Chemical Weathering Rates of Silicate Mineral (Vol. 31, pp. 407-461). 
Washington DC: Mineralogical Soc. America, Reviews in Mineralogy.

https://doi.org/10.1515/9781501509650-011

Whittig, L. D., \& Jackson, M. L. (1954). Interstratified Layer Silicates in Some Soils of Northern Wisconsin. Clays and Clay Minerals, 3, 332-336.

https://doi.org/10.1346/CCMN.1954.0030126 